\title{
Correction to: Predisposing and triggering factors of large-scale landslides in Debre Sina area, central Ethiopian highlands
}

\author{
Tesfay Kiros Mebrahtu ${ }^{1} \cdot$ Bedru Hussien ${ }^{2} \cdot$ Andre Banning $^{1} \cdot$ Stefan Wohnlich ${ }^{1}$
}

Published online: 7 September 2021

(c) The Author(s) 2021

\section{Correction to: Bulletin of Engineering Geology and the Environment (2021) 80:365-383 https://doi.org/10.1007/s10064-020-01961-1}

The article "Predisposing and triggering factors of largescale landslides in Debre Sina area, central Ethiopian highlands", written by Tesfay Kiros Mebrahtu, Bedru Hussien, Andre Banning and Stefan Wohnlich, was originally published Online First without Open Access. After publication in volume 80 , issue 1 , page $365-383$ the author decided to opt for Open Choice and to make the article an Open Access publication. Therefore, the copyright of the article has been changed to (C) The Author(s) 2020 and the article is forthwith distributed under the terms of the Creative Commons Attribution 4.0 International License, which permits use, sharing, adaptation, distribution and reproduction in any medium or format, as long as you give appropriate credit to the original author(s) and the source, provide a link to the Creative Commons licence, and indicate if changes were made. The images or other third party material in this article are included in the article's Creative Commons licence, unless indicated otherwise in a credit line to the material. If material is not included in the article's Creative Commons licence and your intended use is not permitted by statutory regulation or exceeds the permitted use, you will need to obtain permission directly from the copyright holder. To view a copy of this licence, visit http://creativecommons. org/licenses/by/4.0.

The original article has been corrected.

Open Access This article is licensed under a Creative Commons Attribution 4.0 International License, which permits use, sharing, adaptation, distribution and reproduction in any medium or format, as long as you give appropriate credit to the original author(s) and the source, provide a link to the Creative Commons licence, and indicate if changes were made. The images or other third party material in this article are included in the article's Creative Commons licence, unless indicated otherwise in a credit line to the material. If material is not included in the article's Creative Commons licence and your intended use is not permitted by statutory regulation or exceeds the permitted use, you will need to obtain permission directly from the copyright holder. To view a copy of this licence, visit http://creativecommons.org/licenses/by/4.0/.
The original article can be found online at https://doi.org/10.1007/ s10064-020-01961-1.

\section{Tesfay Kiros Mebrahtu}

tesfay.mebrahtu@rub.de

1 Institute of Geology, Mineralogy and Geophysics, Department of Applied Geology, Ruhr University of Bochum, Bochum D-44780, Germany

2 Department of Geology, Addis Ababa Science and Technology University, P.O. Box 16417, Addis Ababa, Ethiopia 